Acta Univ. Sapientiae, Social Analysis, 9 (2019) 29-52

DOI: 10.2478/aussoc-2019-0003

\title{
Mapping Homogamy of Noble Descendants in Poland. A Case Study of the Genealogy of Descendants of the Great Sejm ${ }^{1}$
}

\author{
Marek JERZY MINAKOWSKI \\ Dr Minakowski Publikacje Elektroniczne, Poland \\ mj@minakowski.pl \\ Rafal SMOCZYNSKI \\ Polish Academy of Sciences, Warsaw, Poland \\ rsmoczyn@ifispan.waw.pl
}

\begin{abstract}
Since 2005, a unique project has been under way, which aims to collect all possible descendants of the parliamentary élite of the $18^{\text {th }}$-century Polish-Lithuanian Commonwealth (Rzeczpospolita). The project resulted in creating an online database called The Genealogy of Descendants of the Great Sejm, which provides a unique source of information about the genealogical structure of people descending from the $18^{\text {th }}$-century noble élite of the PolishLithuanian Commonwealth. Drawing on these data, this paper aims to open up new lines of inquiry on the dynamics of homogamy of the Polish nobility by analyzing longer trends of several (e.g. five, eight, or even more) generations of nobles (or nobles' descendants) in Poland over the last two centuries.
\end{abstract}

Keywords: Polish nobility, homogamy, descendants of Sejm Wielki, reproduction of historical élites

\section{Defining the Problem}

The contemporary European nobility has recently attracted some attention in the sociology of élites, with arguably the best-analyzed case of nobility in the Netherlands. Jaap Dronkers, Huibert Schijf (Dronkers 2008, 2003; Dronkers-

1 Rafal Smoczynski acknowledges that certain aspects of this paper were developed during the project supported by the Polish Academy of Sciences and the Romanian Academy (Expanding Research on Family in Poland and Romania) as well as the project supported by the Polish Academy of Sciences and the Hungarian Academy of Sciences (The Role of Intelligentsia in Shaping Collective Identities of Poles and Hungarians in $19^{\text {th }}$ and $20^{\text {th }}$ Centuries). 
Schijf 2004), and their collaborators carefully examined the social reproduction processes of the Dutch nobility, and one of their major findings suggests that the very possibility of keeping the continued social relevance of this group contradicts selected intuitive assumptions of the modernization theory. For instance, the Dutch nobility, instead of gradually experiencing the decomposition of its kin networks and adjusting to the structural position of modern nuclear family units, upholds its post-feudal networks functioning as an indispensable social environment not only for the primordial socialization of their offspring but also for practicing homogamy. Although homogamy has been declining over the last decades in the Netherlands, it still has been significantly more frequently identified among nobility than among members of another analyzed control group (high bourgeoisie). Also, members of the Dutch nobility successfully use their specific cultural capital resources that are being accumulated within kin networks to facilitate their competitiveness for highly esteemed jobs. Consequently, this milieu has managed to maintain an overrepresentation in prestigious professional and public services in the Netherlands (again as compared with bourgeoisie members). The literature brings also qualitative studies on the contemporary Swedish, Finnish, French, and Austrian nobility (Åström 2007, de Saint Martin 2007, Korom-Dronkers 2015, Norrby 2015), and recently there has been a growing line of inquiries on Eastern European nobility carried out especially in Poland and Hungary (Jakubowska 2012, 2009, 2005; Smoczyński-Zarycki 2012; Sztárayné Kézdy 2009).

Even though the Eastern European nobility's land properties were confiscated after 1944 and a noble milieu suffered prosecutions what apparently led to its disappearance in the communist bloc - as some recent work demonstrated -, postfeudal elites mainly of aristocratic descent managed to sustain comprehensive family bonds and expressive social rituals (Jakubowska 2012). In explaining reasons for their continued relevance, Smoczyński and Zarycki (2012) argued that the vitality of the former feudal elites in Poland should be attributed to the rich cultural and social capital resources that have been accumulated within this milieu. Following earlier discoveries in the Netherlands, where the possibility of maintaining the coherent noble milieu was significantly underpinned by the ongoing homogamy, it would be also interesting to examine if this practice also applies to the Eastern European nobility.

Historically, in pre-20 $0^{\text {th }}$-century Poland, homogamy functioned as one of the major factors perpetuating a stable noble identity over generations but also contributed to the accumulation of material and symbolic resources within kin networks. Unfortunately, the current research exploring a Polish noble milieu has been constrained in its exploratory capability aiming at establishing precise figures on the rate of this milieu's homogamy. One of the reasons for this difficulty is related to the Polish republican political system, which does not officially 
recognize noble titles; thus, the very definition of collective identity of analyzed individuals who either self-report that are of noble origin or are perceived as nobility is inchoate. Also the rules of belonging to a contemporary noble community are not precise. For instance, a comprehensive study of Smoczyński and Zarycki on the $21^{\text {st }}$-century Polish nobility (Smoczyński-Zarycki 2017) has not brought decisive findings, which would corroborate their qualitative indications about the ongoing relevance of homogamy practiced by this community. Moreover, to our best knowledge, there are no other studies examining a current noble homogamy either in Poland or in other Eastern European countries.

Besides limitations set by the republican system, which does not allow to use reliable formal criteria to operationalize a noble identity, there are other factors which may hinder opening new avenues on the possible perpetuation of their homogamy or the lack thereof. For instance, concerning the coherent but an informal post-feudal network that includes several dozens of Polish aristocratic descendants - even though it has been consistently named as a noble milieu by the mass media -, its rules of belonging are not actually governed by the historical criterion of noble origin. In Poland, the latter has traditionally been informed with the logic of a patrilineal noble generation renewal, whereas the current milieu that is commonly perceived as nobility includes not only matrilineal-criterion-based descendants but even people of entirely non-noble origin. The latter individuals are accepted as participants of this informal group's social activities insofar as they remain in a certain familial affinity (even distant) with its major actors. Since there are no officially recognized criteria of nobility, the only available membership criterion is based on the perceived fact of "living" and on persistent socialization with the informal noble milieu. Eventually, there is no basis for computing the statistical regularities of noble homogamy in contemporary Poland. Given these difficulties constraining the possibility of designing a representative survey sampling, we are confronted with different types of proxies which may map the possible terrain of noble homogamy in Poland. Smoczyński and Zarycki (2012, 2017) employed a qualitative inquiry which brought an interview-databased support to assume (modestly) the ongoing relevance of noble homogamy, particularly practiced among post-aristocratic family members.

The possible innovativeness of this research lies, on the one hand, in strengthening the scholarship on the reproduction practices of the noble descendants in Eastern Europe, while, on the other, these findings may also provide an important point of reference in the ongoing discussion on the limits and applicability modes of the modernization theory. 


\section{The Genealogy of Descendants of the Great Sejm}

New possible lines of inquiry on the dynamic of noble homogamy could be opened up by analyzing longer trends of several (e.g. five, eight, or even more) generations of nobles (or nobles' descendants). Fortunately, since 2005, a unique project has been under way, which aims to collect all possible descendants of the parliamentary élite of the $18^{\text {th }}$-century Polish-Lithuanian Commonwealth (Rzeczpospolita). The project resulted in creating an online database, called The Genealogy of Descendants of the Great Sejm (Minakowski 2018a), and in forming a non-government organization, Stowarzyszenie Potomków Sejmu Wielkiego (Stowarzyszenie Potomków Sejmu Wielkiego, n.d.), which received formal patronage from the Speaker of Parliament of Poland and was officially accepted by the President of Lithuania.

The Genealogy of Descendants of the Great Sejm (the database) has precisely defined borders: it is aiming to collect all (almost 500) Members of Parliament of the Polish-Lithuanian Commonwealth in the term 1788-1792. The Great Sejm (also called: Sejm Czteroletni, Four-Year Sejm) was the parliament that passed the first European constitution on May $3^{\text {rd }}$, 1791, and its members were as famous in Poland as the Founding Fathers in the United States (Żychliński 1879). Apart from members of all three houses of the Parliament, data on their parents, siblings (from a patrilineal and matrilineal approach), and all of their descendants (descendants of members and their siblings) are also collected up to present times (2018 so far). If any of those people were/are married, then data on their marriages, spouses, and the spouses' parents are collected, too.

Over the years, the number of people in the database has slowly grown, and recently only single families have been added, which obviously do not represent any great, forgotten branches. Also, new collections of archival data, available online since recent years, add less new people. Therefore - although it will probably never be possible to determine the exact number of the descendants of the $18^{\text {th }}$-century upper-class that are still living -, the database can be used as a proxy for quite good approximation.

As for mid-2018, there are over 128,000 people listed there: 494 members of Sejm Wielki (representatives elected in 1788 and 1790, senators, and the king) and over 40,000 direct descendants (great-great-grandsons, great-greatgranddaughters, etc.), accompanied by the next over 27,000 descendants of siblings of the Sejm members. The data were also collected on their spouses, who do not represent preceding categories (over 30,000 people), and their parents (almost 30,000 people).

The Genealogy is part of another, larger project, called Minakowski's Great Genealogy, published online at Wielcy.pl (Minakowski 2018b). The methodological issues (sources and methods of gathering data) have been published in several 
articles (Minakowski 2016, 2007). The main sources for the Genealogy of the Descendants of Great Sejm for the $18^{\text {th }}$ century are printed biographies of $18^{\text {th }}$ century politicians and printed genealogies of their families (PSB 1935). Some genealogical data were inferred directly from $18^{\text {th }}$-century documents, usually concerning the land ownership (Świca et al. 1997). At the beginning of the $19^{\text {th }}$ century, the modern system of civil registration was introduced, especially in the lands conquered by the Napoleonic army, where the French Civil Code was introduced (in the Duchy of Warsaw). E.g., for the period of 1806-1914, we have found and analyzed about 6,000 acts of marriage related to the descendants, each describing at least six people (spouses and their parents). In the Powązkowski Cemetery in Warsaw, the author found graves of 5,664 people from the database; as for 2005, the author found an obituary in Kurier warszawski between 1821 and 1861. And 15,375 people are mentioned in Polski słownik biograficzny ("Polish Biographical Dictionary") as people having their own entries or as members of their close families (Polski słownik biograficzny, 1935).

During over 15 years of developing the Genealogy of Descendants of Great Sejm, the author received tens of thousands of letters or e-mails from people who wanted to share their archives to preserve it for future generations. Most of the data originate from people born before or about the middle of the $20^{\text {th }}$ century - who personally remembered people born in the $19^{\text {th }}$ century (their parents or grandparents), when the social distance between nobility and the rest of the society was still significant. Some parts of the data are obtained from such private archives. There is a good reason for this strategy: if one intends to find all descendants of the Great Sejm, one should assume that some of them are not well documented by public documents. In such cases, the author relies on the trustworthiness of private archives (especially when the social status of their owners speaks for their credibility). The reliability of these documents is reinforced by the fact that the only editor of the database can include any documents into the genealogy, while users can only obtain a reader status, being unable to change the data. If the editor does not consider the information credible, he just ignores it. Further, the reliability is ensured by the fact that the whole database is an open access system and free of charge: if any piece of information is disputable, people report it. For instance, the $19^{\text {th }}$-century ancestors have usually many descendants who often did not know each other. The author can therefore cross-check the information with different branches of the same family. We should also remember that there is some number of people who are nitpickers and enjoy criticism in showing holes in somebody else's genealogy. Of about 60,000 people visiting Genealogy each month, several of them are such nitpickers.

If we further discuss the credibility of the data, different measures should be applied to people born in early $19^{\text {th }}$ century (for them, the archival records or printed books are widely available) and for people born in the $20^{\text {th }}$ century who 
are subject to the laws enforcing privacy. On the other hand, an error in recent genealogy does not bear serious consequences, while an error in attributing a branch of family in early $19^{\text {th }}$ century can be disastrous. Fortunately, the more we go back in time, the less information is taken from private sources and more from printed documents.

Minakowski's Great Genealogy started with the detailed analysis of the 16-volume Adam Boniecki's Herbarz Polski (18 million characters) (Narojczyk 2003), which became the foundation of the database. Boniecki's Herbarz (Boniecki 2002) is considered to be the most important source for Polish noble genealogy (Dworzaczek 1959). Boniecki employed the following methodology: he obtained the data drawing on official documents published or kept in archives (he usually did not visit archives himself but used excerpts prepared for him by professional archivists); he provided references each time (usually volume and page number). But official documents did not constitute his major data source. Boniecki's genealogy was completed by adding information from personal documents and private genealogies when they appeared reliable. This was a very important methodological qualification: focusing only on facts obtained from official documents would have made the whole genealogy too fragmented; and what is even worse - official documents were often forged (e.g. notarized by a notary public on the basis of previously forged documents). Boniecki assessed informants' trustworthiness on the basis of his personal relations with them and on the basis of the perceived relation between informants and the people they gave an account of. For instance, Boniecki knew that somebody who wrote about his/her great-grandparents was usually reliable, but when the same person wrote about his ancestors from the $16^{\text {th }}$ century, it was not so reliable.

Boniecki's methodology in gathering data was adopted ever since in Minakowski's genealogy: Minakowski builds on original documents (keeping track of the sources), but he also uses private genealogies when their owners seem credible (four or five generations back, to the great-grandparents of their grandparents). There should be also noted that he keeps record of the source of every single piece of information entered into the database. If it was taken from a private letter and not from a printed book, he can always find the letter in our archive and check it once again.

The remainder of this paper includes the following: we briefly describe the peculiarity of the Polish nobility and its late $18^{\text {th }}$-century parliamentary system, whose representatives made up the analyzed Sejm Wielki members' descendants, and then we calculate the data and conclude the paper. 


\section{The Political System of the Noble Republic and Limitations of the Research}

Since the late Middle Ages until the end of the $18^{\text {th }}$ century, the vast territory of Eastern Europe, which now constitutes five independent countries, formed a union. Namely, in 1569, the delegates of the Polish Crown and the Grand Duchy of Lithuania signed the Union of Lublin, turning them into a single state whose area covered approximately present-day Poland, Lithuania, Latvia, Belarus, and Ukraine. The Polish-Lithuanian Commonwealth, called Rzeczpospolita, emerged through aggregation rather than conquests, which meant that their political elites were of local origin, and they did not represent conquerors or governors sent from metropolises. The monarch was actually the President of the Union, freely elected by nobles, who made up about $10 \%$ of the society. The noblemen had the right to own a piece of land, participate in a local assembly ("sejmik"), and elect representatives to the general assembly ("sejm walny", which had to be called every second year); finally, they were obliged to defend a country (personally as mounted knights). All these rights and obligations were patrilinearily passed to new generations.

The political system of Rzeczpospolita was subject to only minor changes over the centuries. In turn, until the $19^{\text {th }}$ century, the social system of Rzeczpospolita (when Poland had already been partitioned by Prussia, Russia, and Austria) was divided into a number of separated hereditary estates of noblemen, peasants, burghers, and Jews. All estates had their own judiciary systems regulating economic, religious, and political life. This, of course, cemented a practice of homogamy within separate estates, which remained almost intact over several centuries until the beginning of the $19^{\text {th }}$ century, when the class barriers between the nobility and the bourgeoisie were weakened, and members of these classes gradually started to intermarry. To some extent, this novel practice also applied to Jews on the condition that they converted to Christianity (there were virtually no interreligious marriages at that time). The only exceptions were peasants. They constituted the vast majority of Polish society, but, even when in the middle of the $19^{\text {th }}$ century serfdom was terminated, the rate of intermarriages between peasants and other class members was very low. The situation changed significantly in the $20^{\text {th }}$ century, particularly after the Second World War. Therefore, while discussing the genealogy of Polish elites before the early $20^{\text {th }}$ century, we can ignore peasants in our calculations and also burghers and Jews before the early $19^{\text {th }}$ century (Minakowski 2018b).

When the last free parliamentary elections of the Polish-Lithuanian Commonwealth were called in 1788 and 1790 (after which the partition was completed), 180 delegates were sent to Warsaw from their 63 constituencies, covering the whole territory of Rzeczpospolita. In the remainder of this paper, 
we will examine the evolution of the practice of homogamy of the descendants of these 180 Sejm Wielki members over the next two and a half centuries, on whom information was collected in Minakowski (2018b).

The authors do not claim that the Sejm Wielki descendants immutably represented the Polish political and cultural elite of Rzeczpospolita over the entire analyzed period of time. Neither it is stated that the data are representative and complete in terms of giving an account of the evolution of Polish noble élites over past centuries. Besides the fact that individuals recorded in the data were not selected from the statistical subset which would represent features of the whole population, there was also a decisive change in the $19^{\text {th }}$ - and $20^{\text {th }}$-century Polish élite reproduction practices, which must affect the estimation of the analyzed individuals' identity. The intelligentsia, the new collective social actor, gradually started to replace the feudal nobility in defining Polish national interests from the $19^{\text {th }}$ century onwards. Therefore, except for $18^{\text {th }}$-century born individuals who are recorded in Minakowski's Great Genealogy, individuals representing $19^{\text {th }}$ - and $20^{\text {th }}$-century cohorts had been successively affected by modernization processes, which redefined, hybridized, and eventually changed their feudal identities.

Even though most of the intelligentsia members in the $19^{\text {th }}$ and early $20^{\text {th }}$ centuries were of gentry origin (however, we cannot deny the fact that the growing numbers of bourgeois and ethnic minorities were also entering the ranks of this new class), they represented an entirely new social and political collective identity; to mention just the most relevant features: the intelligentsia commonly held that power (either political, economic, or cultural) should be vested in citizens on the basis of their meritocratic skills instead of relying on hereditary resources - thus, most of the intelligentsia members were inclined towards new democratic politics. Also, the intelligentsia's offsprings socialized within the nuclear family units rather than in feudal kin networks (Jedlicki 2008).

This long process of the redefinition of the Polish elite identity, of course, also affected the identity of the Great Sejm descendants, many of whom - due to different reasons - must have gradually assumed new class positions in the $19^{\text {th }}$ and, particularly, in the $20^{\text {th }}$ century. Therefore, the calculations presented below cannot be understood as an analysis of noble homogamy per se, given the growing intertwining of nobility with the intelligentsia and also, to a lesser extent, with members of other classes. The possibility of carrying out the class analysis based on the Genealogy of Descendants of the Great Sejm exceeds, however, the scope of this research, which is concerned merely with the familial relations of the individuals recorded in the dataset. 


\section{Calculations}

In this chapter, we will present the results of the statistical analysis of homogamy of descendants of the $18^{\text {th }}$-century political élite of the Polish-Lithuanian Commonwealth, or The Rzeczpospolita. At first, we will present the size and structure of the parliamentary members' group (deputies, senators) of the 17881792 parliament (The Great Sejm). Next, we will present our calculations of their descendants' homogamy practices: the parliamentary members' (and their siblings') children, grandchildren, great-grandchildren, etc. living in subsequent centuries (until the $21^{\text {st }}$ century). This, in turn, will allow us to see how the descendent groups of representatives of various regions of The Rzeczpospolita interacted between themselves: whether they married within the groups defined by their geographical origins or rather formed one, coherent, "cosmopolitan" élite. We will be able to see the dynamic of the process in time.

The calculations will be complicated by the fact that the analyzed groups had never been homogenous and even; the political system of Rzeczpospolita had a long history and the number of representatives at the end of the $18^{\text {th }}$ century was not proportional either to the numbers of inhabitants or to the area of provinces. We will need to take this into account and adjust the numbers to see the real social process. Hence, we will divide the area of Rzeczpospolita into seven regions and proportionally adjust the size of their elites as if they were equal in number. The details of these calculations, their conditions and results, are discussed in turn.

Currently (spring 2018), the Genealogy of the Descendants of the Great Sejm consists of:

- 494 members of the Sejm (the King, elected members, and senators who swore to the act of "confederation of the parliamentary estates");

$-40,725$ direct descendants;

$-27,161$ siblings and direct descendants;

$-30,081$ spouses of the above;

-29,658 parents of all the above (including parents of spouses of the above).

All that makes 128,119 individuals. Out of them, 18,000 were born in the $18^{\text {th }}$ century, 50,000 in the $19^{\text {th }}$ century, and 56,000 in the $20^{\text {th }}$ century. 3,500 were born already in the $21^{\text {st }}$ century. 
Table 1. The members of the Great Sejm

\begin{tabular}{|c|c|c|}
\hline Constituency & Total & $\begin{array}{c}\text { Lower house } \\
\text { only }\end{array}$ \\
\hline King & 1 & 0 \\
\hline Central senators & 8 & 0 \\
\hline \multicolumn{3}{|l|}{ Polish Crown } \\
\hline Duchy of Livonia - on behalf of the Crown & 4 & 4 \\
\hline \multicolumn{3}{|l|}{ Masovia, now in Poland: } \\
\hline Duchy of Masovia & 48 & 39 \\
\hline Voivodeship of Rawa Mazowiecka & 16 & 13 \\
\hline Voivodeship of Płock & 14 & 8 \\
\hline \multicolumn{3}{|l|}{ Greater Poland, now in Poland } \\
\hline Voivodeship of Brześć Kujawski & 10 & 4 \\
\hline Voivodeship of Chełmno & 2 & 0 \\
\hline Voivodeship of Gniezno & 10 & 8 \\
\hline Voivodeship of Inowrocław & 11 & 8 \\
\hline Voivodeship of Kalisz & 20 & 16 \\
\hline Voivodeship of Łęczyca & 12 & 8 \\
\hline Voivodeship of Malbork (Marienburg) & 1 & 0 \\
\hline Voivodeship of Pomorze (Pomerania) & 3 & 0 \\
\hline Voivodeship of Poznań & 22 & 16 \\
\hline Voivodeship of Sieradz & 16 & 12 \\
\hline \multicolumn{3}{|l|}{ Lesser Poland, now in Poland } \\
\hline Voivodeship of Cracow & 22 & 16 \\
\hline Voivodeship of Lublin & 14 & 12 \\
\hline Voivodeship of Podlasie & 13 & 12 \\
\hline Voivodeship of Sandomierz & 19 & 13 \\
\hline \multicolumn{3}{|l|}{ Now in Ukraine } \\
\hline Voivodeship of Bełz & 7 & 0 \\
\hline Voivodeship of Bracław & 13 & 12 \\
\hline Voivodeship of Czernihov & 11 & 8 \\
\hline Voivodeship of Kiev & 20 & 13 \\
\hline Voivodeship of Podole & 15 & 14 \\
\hline Voivodeship of Ruthenia (Lviv) & 9 & 4 \\
\hline Voivodeship of Volhynia (Wołyń) & 15 & 12 \\
\hline \multicolumn{3}{|l|}{ Grand Duchy of Lithuania } \\
\hline Central & 8 & 0 \\
\hline Duchy of Livonia (Inflanty) - on behalf of Lithuania & 4 & 4 \\
\hline \multicolumn{3}{|l|}{ Now in Lithuania: } \\
\hline Duchy of Samogitia (Żmudź, Žemaitija) & 15 & 12 \\
\hline
\end{tabular}




\begin{tabular}{lcc}
\hline Constituency & Total & $\begin{array}{c}\text { Lower house } \\
\text { only }\end{array}$ \\
\hline Voivodeship of Trakai (Troki) & 18 & 17 \\
\hline Voivodeship of Vilna (Vilnius) & 24 & 20 \\
\hline Now in Belarus: & 10 & 8 \\
\hline Voivodeship of Brest (Brześć Litewski) & 14 & 12 \\
\hline Voivodeship of Minsk (Mińsk Litewski) & 2 & 0 \\
\hline Voivodeship of Mścisław & 13 & 12 \\
\hline Voivodeship of Nowogródek & 6 & 4 \\
\hline Voivodeship of Połock & 11 & 8 \\
\hline Voivodeship of Smoleńsk & 7 & 4 \\
\hline Voivodeship of Vitebsk & & \\
\hline Now in Latvia: & 6 & 4 \\
\hline Duchy of Livonia - on behalf of itself & & \\
\hline Sourcatho
\end{tabular}

Source: authors' work based on the list of members of parliament who swore to the Act of Confederation, published in Volumina Legum (Jakubowski et al. 1889: 46-51, 205-209), and several acts of senators who swore to it later, separately.

Please note that their relative numbers vary, which reflects the history of the region. E.g., the Duchy of Masovia, which was an independent state until 1529, had its own political structure, retained after its incorporation into the Crown. That is why the rule of liberum veto was so vital: every constituency had the same right to breach the Sejm, and everybody's interest should be considered equally (despite the number of seats in the Parliament).

\section{Intermarriage between Regional Elites}

The "Great Sejm" counted 494 members altogether. To analyze the intermarriage rate between regional elites, we should ignore its members representing the central authorities: the King (Stanislas August) and 16 senators ("ministers" 8 from the Crown and 8 from Lithuania: great and minor marshals, treasurers, chancellors, and hetmans). The Duchy of Livonia (in Polish: Księstwo Inflanckie), now in Latvia, had a special status: there were 6 representatives of Livonia itself, and Lithuania and the Crown delegated 8 additional ones (4 from the Crown and 4 from Lithuania) - we will disregard those additional ones.

We are left with 369 members, who represented the area of $21^{\text {st }}$-century Belarus: 63, Lithuania: 57, Latvia: 6, Ukraine: 90, and Poland: 253. The current area of Poland dominates; so, let us split it into three major provinces: Greater Poland, Lesser Poland, and Mazovia. Following this classification, we receive a more even distinction: 
Table 2. Members of the Great Sejm divided into large regions, based on current political borders

\begin{tabular}{lc}
\hline Belarus (BY) & 63 \\
\hline Lithuania (LT) & 57 \\
\hline Latvia (LV) & 6 \\
\hline Mazovia (PL-maz) & 78 \\
\hline Greater Poland (PL-wp) & 107 \\
\hline Lesser Poland (PL-mp) & 68 \\
\hline Ukraine (UA) & 90 \\
\hline
\end{tabular}

Source: Genealogy of the Descendants of the Great Sejm

Of course, one person can be (and often is) a descendant of many members of the Great Sejm. If we count all their known direct descendants (from the $18^{\text {th }}$ century until 2018), we receive the numbers from 255 (Latvia) to 17,205 (Greater Poland). Adding descendants of the Great Sejm members' siblings, these numbers will grow from 2,635 (Latvia) to 36,513 (Greater Poland).

Table 3. The numbers of known descendants of members of the Great Sejm and of descendants of their siblings

\begin{tabular}{lccc}
\hline Region & $\begin{array}{c}\text { Members of the } \\
\text { Great Sejm }\end{array}$ & Direct descendants & $\begin{array}{c}\text { With descendants } \\
\text { of siblings }\end{array}$ \\
\hline Belarus & 63 & 6,670 & 13,115 \\
\hline Lithuania & 57 & 5,744 & 11,800 \\
\hline Latvia & 6 & 255 & 2,635 \\
\hline $\begin{array}{l}\text { Mazovia (now } \\
\text { in Poland) }\end{array}$ & 78 & 12,719 & 22,252 \\
\hline $\begin{array}{l}\text { Greater Poland } \\
\text { (now in Poland) }\end{array}$ & 107 & 17,205 & 23,446 \\
\hline $\begin{array}{l}\text { Lesser Poland } \\
\text { (now in Poland) }\end{array}$ & 68 & 14,312 & 36,513 \\
\hline Ukraine & 90 & 13,546 & 23,544 \\
\hline
\end{tabular}

How many generations do we know since the $18^{\text {th }}$ century? Let us count the distinct pairs of a Sejm member and his descendants (direct or sibling descendants). People who descend from $n$ Sejm members are counted $n$ times: 
Table 4. Number of unique pairs: the members of Great Sejm and their descendants or descendants of their siblings

\begin{tabular}{cc}
\hline Generation & Number of pairs: member-descendant \\
\hline 0 & 2,555 \\
\hline 1 & 5,200 \\
\hline 2 & 10,130 \\
\hline 3 & 19,059 \\
\hline 4 & 31,044 \\
\hline 5 & 45,098 \\
\hline 6 & 62,539 \\
\hline 7 & 89,383 \\
\hline 8 & 92,539 \\
\hline 9 & 41,302 \\
\hline 10 & 7,541 \\
\hline 11 & 507 \\
\hline 12 & 25 \\
\hline
\end{tabular}

Source: Genealogy of the Descendants of the Great Sejm

Instead of counting generations (which are linked to a specific ancestor and thus multiplied), we can count the birth dates. This is the statistics for distinct people who were members of the Great Sejm or their siblings or who are descendants of any of them.

Table 5. Number of descendants of the Great Sejm members or their siblings split by the birth date (in decades)

\begin{tabular}{|c|c|c|c|c|c|c|c|c|c|}
\hline $\begin{array}{c}\text { Birth } \\
\text { decade }\end{array}$ & No. & $\begin{array}{c}\text { Birth } \\
\text { decade }\end{array}$ & No. & $\begin{array}{c}\text { Birth } \\
\text { decade }\end{array}$ & No. & $\begin{array}{c}\text { Birth } \\
\text { decade }\end{array}$ & No. & $\begin{array}{c}\text { Birth } \\
\text { decade }\end{array}$ & No. \\
\hline & & 170. & 25 & 180. & 1,544 & 190. & 3,379 & 200. & 2,882 \\
\hline & & 171. & 73 & 181. & 1,837 & 191. & 2,540 & 201. & 838 \\
\hline & & 172. & 247 & 182. & 2,062 & 192. & 3,094 & & \\
\hline & & 173. & 430 & 183. & 2,279 & 193. & 2,634 & & \\
\hline & & 174. & 621 & 184. & 2,664 & 194. & 2,760 & & \\
\hline & & 175. & 708 & 185. & 2,919 & 195. & 3,693 & & \\
\hline & & 176. & 728 & 186. & 3,127 & 196. & 2,923 & & \\
\hline & & 177. & 953 & 187. & 3,184 & 197. & 3,726 & & \\
\hline 168. & 4 & 178. & 1,281 & 188. & 2,919 & 198. & 4,532 & & \\
\hline 169. & 5 & 179. & 1,220 & 189. & 3,359 & 199. & 3,175 & & \\
\hline
\end{tabular}

The same results are summed up in centuries in the following table. 
Table 6. Number of descendants of the Great Sejm members or their siblings split by the birth date (in centuries)

\begin{tabular}{cc}
\hline Century & No. \\
\hline $16 .$. & 9 \\
\hline $17 .$. & 6,286 \\
\hline $18 .$. & 25,894 \\
\hline $19 .$. & 32,456 \\
\hline $20 .$. & 3,720 \\
\hline & Source: Genealogy of the Descendants of the Great Sejm
\end{tabular}

Having defined the analyzed group, we will test whether the Great Sejm members' descendants from various regions:

a) intermarried mostly within their regional groups (i.e. married usually people descending from the élite of the same region) or

b) quickly established familial relations and merged into one group, where their geographical origins are hard to notice or

c) initially intermarried within regional groups (e.g. in Ukraine, Lithuania, Lesser Poland) and in some time gradually changed their matrimonial practice to form one great family without geographical differences.

We will define "intermarriage case" as a single moment when two distinct persons get married or a child is born to an unmarried couple and both spouses (parents) are descendants of the members of the Great Sejm or their siblings. Thus, the "intermarriage case" is a distinct quadruplet consisting of two "descendants" (spouses or unmarried parents) and two "ancestors" (members of the Great Sejm or their siblings). We do not check whether "descendant" is different from "ancestor", and so we also count descendants in "generation 0", i.e. the intermarriage cases of the Great Sejm members themselves and their siblings when, e.g., member A of the Great Sejm married sister B. of a senator C. (in such a case, A. is counted as "a descendant" of A. himself and B. is "a descendant" of C.).

Table 7 shows the total number of marriages of the descendants of the Great Sejm (including descendants of the Great Sejm members' siblings), split by half a century. As we said above, a descendant is anyone whose any ancestor is a father or a mother of a member of the Great Sejm. All other people can be called nondescendants. So, a non-descendant is someone who does not have any known ancestor who was a member of the Great Sejm or even who was a father or a mother of a member of the Great Sejm. 
Table 7. Cases of intermarriage between descendants of the Great Sejm and non-descendants

\begin{tabular}{ccccc}
\hline $\begin{array}{c}\text { Half a } \\
\text { century }\end{array}$ & $\begin{array}{c}\text { Both spouses } \\
\text { are descendants }\end{array}$ & $\begin{array}{c}\text { Husband is a } \\
\text { descendant }\end{array}$ & $\begin{array}{c}\text { Wife is a } \\
\text { descendant }\end{array}$ & $\begin{array}{c}\text { Any spouse is a } \\
\text { descendant }\end{array}$ \\
\hline $1700-49$ & 4 & 51 & 105 & 156 \\
\hline $1750-99$ & 283 & 1,130 & 1,116 & 2,246 \\
\hline $1800-49$ & 839 & 2,446 & 2,768 & 5,214 \\
\hline $1850-99$ & 1,418 & 3,844 & 4,288 & 8,132 \\
\hline $1900-49$ & 1,438 & 5,165 & 5,043 & 10,208 \\
\hline $1950-99$ & 497 & 5,845 & 5,327 & 11,172 \\
\hline $2000-18$ & 89 & 1,241 & 1,093 & 2,334 \\
\hline
\end{tabular}

Source: Genealogy of the Descendants of the Great Sejm

The differences between genders and between descendants of senators and ordinary members of parliament will be discussed further on. Now, let us focus on the intermarriage cases of the analyzed group's members, taking place between different regions of the former Rzeczpospolita.

Table 8. Intermarriage cases between descendants of the Great Sejm members representing specific regions

\begin{tabular}{cccccccc}
\hline 1700-49 & BY & LT & LV & PL-maz & PL-mp & PL-wp & UA \\
\hline BY & 1 & 0 & 0 & 0 & 0 & 0 & 0 \\
\hline LT & 0 & 1 & 0 & 0 & 0 & 0 & 0 \\
\hline LV & 0 & 0 & 0 & 0 & 0 & 0 & 0 \\
\hline PL-maz & 0 & 0 & 0 & 0 & 0 & 0 & 0 \\
\hline PL-mp & 0 & 0 & 0 & 0 & 0 & 0 & 0 \\
\hline PL-wp & 0 & 0 & 0 & 0 & 0 & 1 & 0 \\
\hline UA & 0 & 0 & 0 & 0 & 0 & 0 & 0 \\
\hline & & & & & & & \\
\hline 1750-99 & BY & LT & LV & PL-maz & PL-mp & PL-wp & UA \\
\hline BY & 16 & 20 & 4 & 7 & 13 & 6 & 14 \\
\hline LT & 20 & 10 & 1 & 4 & 5 & 2 & 14 \\
\hline LV & 4 & 1 & 0 & 0 & 1 & 1 & 2 \\
\hline PL-maz & 7 & 4 & 0 & 34 & 16 & 31 & 19 \\
\hline PL-mp & 13 & 5 & 1 & 16 & 25 & 27 & 31 \\
\hline PL-wp & 6 & 2 & 1 & 31 & 27 & 47 & 14 \\
\hline UA & 14 & 14 & 2 & 19 & 31 & 14 & 36 \\
\hline & & & & & & & \\
\hline 1800-49 & BY & LT & LV & PL-maz & PL-mp & PL-wp & UA \\
\hline BY & 56 & 71 & 14 & 31 & 39 & 32 & 69 \\
\hline LT & 71 & 48 & 11 & 29 & 28 & 21 & 59 \\
\hline LV & 14 & 11 & 4 & 5 & 9 & 7 & 15 \\
\hline
\end{tabular}




\begin{tabular}{|c|c|c|c|c|c|c|c|}
\hline $1800-49$ & BY & LT & $\mathrm{LV}$ & PL-maz & PL-mp & PL-wp & UA \\
\hline PL-maz & 31 & 29 & 5 & 78 & 107 & 109 & 98 \\
\hline PL-mp & 39 & 28 & 9 & 107 & 96 & 111 & 141 \\
\hline PL-wp & 32 & 21 & 7 & 109 & 111 & 234 & 94 \\
\hline UA & 69 & 59 & 15 & 98 & 141 & 94 & 154 \\
\hline 1850-99 & $\mathrm{BY}$ & LT & $\mathrm{LV}$ & PL-maz & PL-mp & PL-wp & UA \\
\hline $\mathrm{BY}$ & 93 & 113 & 24 & 86 & 118 & 126 & 174 \\
\hline $\mathrm{LT}$ & 113 & 90 & 28 & 85 & 112 & 112 & 170 \\
\hline $\mathrm{LV}$ & 24 & 28 & 11 & 16 & 32 & 23 & 37 \\
\hline PL-maz & 86 & 85 & 16 & 158 & 228 & 295 & 222 \\
\hline PL-mp & 118 & 112 & 32 & 228 & 223 & 277 & 304 \\
\hline PL-wp & 126 & 112 & 23 & 295 & 277 & 455 & 302 \\
\hline UA & 174 & 170 & 37 & 222 & 304 & 302 & 318 \\
\hline 1900-49 & $\mathrm{BY}$ & LT & $\mathrm{LV}$ & PL-maz & PL-mp & PL-wp & UA \\
\hline $\mathrm{BY}$ & 151 & 235 & 54 & 272 & 303 & 324 & 359 \\
\hline LT & 235 & 170 & 58 & 272 & 303 & 331 & 357 \\
\hline $\mathrm{LV}$ & 54 & 58 & 11 & 57 & 73 & 60 & 83 \\
\hline PL-maz & 272 & 272 & 57 & 218 & 379 & 492 & 439 \\
\hline PL-mp & 303 & 303 & 73 & 379 & 344 & 541 & 489 \\
\hline PL-wp & 324 & 331 & 60 & 492 & 541 & 562 & 592 \\
\hline UA & 359 & 357 & 83 & 439 & 489 & 592 & 436 \\
\hline 1950-99 & BY & LT & $\mathrm{LV}$ & PL-maz & PL-mp & PL-wp & UA \\
\hline $\mathrm{BY}$ & 96 & 114 & 42 & 176 & 188 & 214 & 190 \\
\hline LT & 114 & 77 & 35 & 161 & 175 & 197 & 173 \\
\hline $\mathrm{LV}$ & 42 & 35 & 5 & 50 & 52 & 61 & 59 \\
\hline PL-maz & 176 & 161 & 50 & 161 & 229 & 285 & 233 \\
\hline PL-mp & 188 & 175 & 52 & 229 & 185 & 298 & 247 \\
\hline PL-wp & 214 & 197 & 61 & 285 & 298 & 254 & 294 \\
\hline UA & 190 & 173 & 59 & 233 & 247 & 294 & 179 \\
\hline 2000-18 & BY & LT & $\mathrm{LV}$ & PL-maz & PL-mp & PL-wp & UA \\
\hline BY & 26 & 34 & 14 & 43 & 45 & 48 & 42 \\
\hline LT & 34 & 26 & 11 & 47 & 48 & 51 & 48 \\
\hline $\mathrm{LV}$ & 14 & 11 & 3 & 16 & 16 & 19 & 16 \\
\hline PL-maz & 43 & 47 & 16 & 36 & 55 & 61 & 56 \\
\hline PL-mp & 45 & 48 & 16 & 55 & 52 & 67 & 56 \\
\hline PL-wp & 48 & 51 & 19 & 61 & 67 & 53 & 64 \\
\hline UA & 42 & 48 & 16 & 56 & 56 & 64 & 47 \\
\hline
\end{tabular}


There are considerable differences in the number of descendants from various regions. Thus, it is difficult to compare the results. For instance, the total number of descendants of the Great Sejm members representing the present area of Lithuania is 11,800 , and the respective value for present area of Ukraine is 23,544 . The differences must have a great impact on the count of intermarriage cases.

We can adopt a countermeasure: we can count the number of intermarriage cases as if the absolute number of descendants of each region were equal. Let us take the number of descendants from Greater Poland, where the number is the highest $(36,513)$, and calculate a factor: how many times the number of descendants for a specific region is less than for Greater Poland. We will use the factor to adjust the values for counting intermarriage cases.

If Lesser Poland has the factor 1.56 and Lithuania the factor 3.09 (because there were 3.09 times less descendants of Lithuanian members of the Great Sejm than its members from Greater Poland), we will multiply the number of intermarriage cases between Lithuania and Lesser Poland by $1.56 \times 3.09$, that is, by 4.82 . Table 9 presents the factors calculated for each region.

Table 9. Factors for comparison between regions as if their representatives had similar numbers of known descendants

\begin{tabular}{lcc}
\hline Region & Descendants & Factor \\
\hline Belarus (BY) & 13,115 & 2.78 \\
\hline Lithuania (LT) & 11,800 & 3.09 \\
\hline Latvia (LV) & 2,635 & 13.9 \\
\hline Mazovia (PL-maz) & 22,252 & 1.64 \\
\hline Greater Poland (PL-wp) & 36,513 & 1 \\
\hline Lesser Poland (PL-mp) & 23,446 & 1.56 \\
\hline Ukraine (UA) & 23,544 & 1.55 \\
\hline
\end{tabular}

In the next step, we present the results (Table 8) multiplied by the factors presented in Table 9. Table 10 shows how many intermarriage cases we have found between descendants originating from any of the seven regions as if the regions had similar numbers of "descendants". In other words, we can read Table 10 in the following way: there are seven regions of Rzeczpospolita which had representatives in the Great Sejm; we adjusted the numbers of their élites to be roughly equal; now, we will check whether (and to what extent) members of these regional élites intermarried. 
Table 10. Cases of intermarriage between descendants of members of the Great Sejm representing specific regions, multiplied by the factors assumed in Table 9

\begin{tabular}{cccccccc}
\hline $1700-49$ & BY & LT & LV & PL-maz & PL-mp & PL-wp & UA \\
\hline BY & 48 & 0 & 0 & 0 & 0 & 0 & 0 \\
\hline LT & 0 & 46 & 0 & 0 & 0 & 0 & 0 \\
\hline LV & 0 & 0 & 0 & 0 & 0 & 0 & 0 \\
\hline PL-maz & 0 & 0 & 0 & 0 & 0 & 0 & 0 \\
\hline PL-mp & 0 & 0 & 0 & 0 & 0 & 0 & 0 \\
\hline PL-wp & 0 & 0 & 0 & 0 & 0 & 3 & 0 \\
\hline UA & 0 & 0 & 0 & 0 & 0 & 0 & 0 \\
\hline
\end{tabular}

\begin{tabular}{cccccccc}
\hline 1750-99 & BY & LT & LV & PL-maz & PL-mp & PL-wp & UA \\
\hline BY & 768 & 944 & 2456 & 145 & 267 & 66 & 294 \\
\hline LT & 944 & 464 & 603 & 82 & 101 & 22 & 289 \\
\hline LV & 2,456 & 603 & 0 & 0 & 262 & 141 & 537 \\
\hline PL-maz & 145 & 82 & 0 & 305 & 142 & 148 & 172 \\
\hline PL-mp & 267 & 101 & 262 & 142 & 219 & 127 & 278 \\
\hline PL-wp & 66 & 22 & 141 & 148 & 127 & 119 & 68 \\
\hline UA & 294 & 289 & 537 & 172 & 278 & 68 & 331 \\
\hline
\end{tabular}

\begin{tabular}{cccccccc}
\hline $1800-49$ & BY & LT & LV & PL-maz & PL-mp & PL-wp & UA \\
\hline BY & 2,688 & 3,35 & 8,596 & 643 & 800 & 353 & 1,449 \\
\hline LT & 3,35 & 2,226 & 6,638 & 592 & 565 & 228 & 1,217 \\
\hline LV & 8,596 & 6,638 & 31,417 & 1,328 & 2,362 & 989 & 4,028 \\
\hline PL-maz & 643 & 592 & 1328 & 700 & 949 & 521 & 890 \\
\hline PL-mp & 800 & 565 & 2,362 & 949 & 842 & 524 & 1,265 \\
\hline PL-wp & 353 & 228 & 989 & 521 & 524 & 595 & 454 \\
\hline UA & 1,449 & 1,217 & 4,028 & 890 & 1,265 & 454 & 1,414 \\
\hline & & & & & & & \\
\hline 1850-99 & BY & LT & LV & PL-maz & PL-mp & PL-wp & UA \\
\hline BY & 4,464 & 5,331 & 14,737 & 1,785 & 2,421 & 1,392 & 3,653 \\
\hline LT & 5,331 & 4,173 & 16,898 & 1,734 & 2,258 & 1,216 & 3,508 \\
\hline LV & 14,737 & 16,898 & 86,396 & 4,248 & 8,397 & 3,25 & 9,936 \\
\hline PL-maz & 1,785 & 1,734 & 4,248 & 1,418 & 2,023 & 1,409 & 2,015 \\
\hline PL-mp & 2,421 & 2,258 & 8,397 & 2,023 & 1,955 & 1,308 & 2,728 \\
\hline PL-wp & 1,392 & 1,216 & 3,25 & 1,409 & 1,308 & 1,156 & 1,459 \\
\hline UA & 3,653 & 3,508 & 9,936 & 2,015 & 2,728 & 1,459 & 2,920 \\
\hline
\end{tabular}




\begin{tabular}{|c|c|c|c|c|c|c|c|}
\hline $1900-49$ & $\mathrm{BY}$ & LT & $\mathrm{LV}$ & PL-maz & PL-mp & PL-wp & UA \\
\hline $\mathrm{BY}$ & 7,249 & 11,087 & 33,157 & 5,646 & 6,216 & 3,579 & 7,537 \\
\hline LT & 11,087 & 7,883 & 35,002 & 5,549 & 6,11 & 3,593 & 7,366 \\
\hline $\mathrm{LV}$ & 33,157 & 35,002 & 86,396 & 15,134 & 19,157 & 8,477 & 22,289 \\
\hline PL-maz & 5,646 & 5,549 & 15,134 & 1,957 & 3,362 & 2,35 & 3,985 \\
\hline PL-mp & 6,216 & 6,11 & 19,157 & 3,362 & 3,016 & 2,554 & 4,388 \\
\hline PL-wp & 3,579 & 3,593 & 8,477 & 2,35 & 2,554 & 1,428 & 2,86 \\
\hline UA & 7,537 & 7,366 & 22,289 & 3,985 & 4,388 & 2,86 & 4,003 \\
\hline 1950-99 & $\mathrm{BY}$ & LT & $\mathrm{LV}$ & PL-maz & PL-mp & PL-wp & UA \\
\hline BY & 4,608 & 5,379 & 25,789 & 3,653 & 3,857 & 2,364 & 3,989 \\
\hline LT & 5,379 & 3,571 & 21,122 & 3,284 & 3,529 & 2,139 & 3,57 \\
\hline $\mathrm{LV}$ & 25,789 & 21,122 & 39,271 & 13,275 & 13,646 & 8,619 & 15,844 \\
\hline PL-maz & 3,653 & 3,284 & 13,275 & 1,445 & 2,031 & 1,361 & 2,115 \\
\hline PL-mp & 3,857 & 3,529 & 13,646 & 2,031 & 1,622 & 1,407 & 2,216 \\
\hline PL-wp & 2,364 & 2,139 & 8,619 & 1,361 & 1,407 & 646 & 1,42 \\
\hline $\mathrm{UA}$ & 3,989 & 3,57 & 15,844 & 2,115 & 2,216 & 1,42 & 1,644 \\
\hline $2000-18$ & $\mathrm{BY}$ & LT & $\mathrm{LV}$ & PL-maz & PL-mp & PL-wp & UA \\
\hline $\mathrm{BY}$ & 1,248 & 1,604 & 8,596 & 893 & 923 & 530 & 882 \\
\hline LT & 1,604 & 1,206 & 6,638 & 959 & 968 & 554 & 990 \\
\hline $\mathrm{LV}$ & 8,596 & 6,638 & 23,563 & 4,248 & 4,199 & 2,684 & 4,297 \\
\hline PL-maz & 893 & 959 & 4248 & 323 & 488 & 291 & 508 \\
\hline PL-mp & 923 & 968 & 4199 & 488 & 456 & 316 & 502 \\
\hline PL-wp & 530 & 554 & 2684 & 291 & 316 & 135 & 309 \\
\hline UA & 882 & 990 & 4297 & 508 & 502 & 309 & 432 \\
\hline
\end{tabular}

Source: Genealogy of the Descendants of the Great Sejm

What can we read from Table 10? Definitely, the case of the Latvian élite is outstanding. However, this may be just an effect of applying a very high factor due to the low number of descendants of Latvian élite. It may also mean that the small Latvian élite had to marry descendants of other regional élites to a greater extent than it was implied by their raw number.

If we do not look at the numbers for Latvia, we can analyze the numbers of intermarriage cases (adjusted by factor, as explained above) and count their relative standard deviation computed as a proportion of standard deviation and average (Table 11). 
Table 11. Relative standard deviation of intermarriage cases between regional élites except Latvian

\begin{tabular}{lcccc}
\hline Period & Average & St. dev. & Relative st. dev. & Sum (adjusted) \\
\hline $1750-99$ & 236 & 221 & $94 \%$ & 8,496 \\
\hline $1800-49$ & 1,002 & 766 & $76 \%$ & 36,065 \\
\hline $1850-99$ & 2,349 & 1,137 & $48 \%$ & 84,566 \\
\hline $1900-49$ & 4,942 & 2,337 & $47 \%$ & 177,900 \\
\hline $1950-99$ & 2,727 & 1,194 & $44 \%$ & 98,164 \\
\hline $2000-18$ & 701 & 363 & $52 \%$ & 25,234 \\
\hline
\end{tabular}

As we can see, in the middle of the $19^{\text {th }}$ century, the relative standard deviation was levelled, and its value (about 50\%) has not changed since then. We believe that the observed differences in the number of intermarriage cases after about 1850 are results of different initial conditions in these regions or are products of the accepted method of adjusting the results.

Before jumping to the next section, one more issue should be addressed. It may have happened that the highest élite (families of senators) was more mobile (or even cosmopolitan) than the lower (families of members of the lower house - posłowie). Maybe we can receive other results if we do not take the families of senators into account. Possibly the families of the members of the lower house of the Great Sejm were more prone to marry only within their regional groups.

Let us then consider marriages where both parties descended from members of the lower house of the parliament. These are the (unadjusted) tables for two most characteristic periods: the beginning of the $19^{\text {th }}$ century (1800-1849) and the end of the $20^{\text {th }}$ century (1950-1999):

Table 12. Absolute numbers of intermarriage cases between people descending from members of the lower house (posłowie)

\begin{tabular}{cccccccc}
\hline 1800-49 & BY & LT & LV & PL-maz & PL-mp & PL-wp & UA \\
\hline BY & 26 & 29 & 5 & 13 & 16 & 13 & 30 \\
\hline LT & 29 & 31 & 9 & 6 & 14 & 7 & 22 \\
\hline LV & 5 & 9 & 3 & 0 & 3 & 2 & 8 \\
\hline PL-maz & 13 & 6 & 0 & 45 & 42 & 48 & 37 \\
\hline PL-mp & 16 & 14 & 3 & 42 & 59 & 53 & 79 \\
\hline PL-wp & 13 & 7 & 2 & 48 & 53 & 155 & 39 \\
\hline UA & 30 & 22 & 8 & 37 & 79 & 39 & 98 \\
\hline 1950-99 & BY & LT & LV & PL-maz & PL-mp & PL-wp & UA \\
\hline BY & 21 & 46 & 15 & 80 & 102 & 106 & 112 \\
\hline LT & 46 & 37 & 17 & 107 & 116 & 127 & 126 \\
\hline
\end{tabular}




\begin{tabular}{cccccccc}
\hline LV & 15 & 17 & 3 & 39 & 42 & 42 & 49 \\
\hline PL-maz & 80 & 107 & 39 & 109 & 186 & 210 & 199 \\
\hline PL-mp & 102 & 116 & 42 & 186 & 157 & 237 & 213 \\
\hline PL-wp & 106 & 127 & 42 & 210 & 237 & 182 & 244 \\
\hline UA & 112 & 126 & 49 & 199 & 213 & 244 & 158 \\
\hline
\end{tabular}

We do not see any sign that the "lower élite" would have behaved differently. The absolute numbers are quite low, so we abstain from calculating standard deviations (the differences may be statistically not significant), but our reading of the numbers does not suggest that we should rethink what was said previously and that we should try to calculate our tables separately for the descendants of the upper and the lower house of the Great Sejm.

\section{Conclusions}

While carrying out our analysis, we aimed, on the one hand, to contribute to the scholarship on the reproduction of the noble descendants in Eastern Europe, while, on the other, by demonstrating the ongoing relevance of the post-feudal collective identity-building practices, we were seeking to provide a point of reference for the ongoing sociological discussion on the limits and applicability modes of the modernization theory. Thus, we turned our attention to Minakowski's database (Minakowski 2018a), which provides unique information on the genealogical structure of people descending from the $18^{\text {th }}$-century noble élite of the PolishLithuanian Union. In our calculation, we tried to capture the key aspect of this structure, focusing on noble homogamy. The first issue addressed in our analysis was concerned with marriages between descendants of the old élite and other people who had not belonged to this group. What we could see is that the rate of homogamy (where both spouses are "descendants of the Great Sejm") was similar in the half centuries 1850-99 and 1900-49 but dropped by two-thirds in the period of 1950-99 (the ratio of both spouses' descendants to any spouse descendant $-17.4 \%, 14.1 \%$, and $4.4 \%$ respectively). For the initial 18 years of the $21^{\text {st }}$ century, the rate was even lower (3.8\%). Obviously, further research - in line with an earlier studied Dutch case (e.g. Dronkers 2003) - will require to contextualize these findings while using a non-noble control group.

Then, we measured homogamy as defined by geographic (regional) origins: we tried to test whether (and to what extent) descendants of regional élites married between or within their regional groups. We defined the regional groups by dividing the whole Union into seven regions. We called the "regional élite" as individuals who represented a given region in the Parliament of 1788-1792. It appeared that about 60 years after the regional élites were defined (i.e. around 
1850) the structure reached a stable form. The regional differences were levelled out, and currently if one descends from a former representative of Greater Poland the likelihood that one's wife descends from a representative of Lithuania, Latvia, or Ukraine is roughly the same as in the second half of the $19^{\text {th }}$ century.

Next, we tried to examine whether "higher" and "lower" élites kept homogamy practices in the same way. It appeared that there is no trace of differences between descendants of senators (upper house of parliament, appointed by a king) and representatives (elected from the local nobles in general elections held in regional assemblies).

\section{References}

Åström, Anna-Maria. 2007. Continuity and Change. The Case of the Savo Gentry in Finland. In: D. Lancien, M. de Saint Martin (eds.), Anciennes et Nouvelles Aristocraties de 1880 à Nos Jours. Paris: Maison des sciences de l'homme. 187-202.

Boniecki, Adam. 2002. Herbarz polski. Wiadomości historyczno-genealogiczne o rodach szlacheckich $\mathrm{Cz}$. 1. Wydanie nowe, elektroniczne wydanie drugie, rozpoznał, zanalizował i zaindeksował dr Marek Jerzy Minakowski.

de Saint Martin, Monique. 2007. L'espace de l'aristocratie en France: Desagregation et recomposition(s). In: D. Lancien, M. de Saint Martin (eds.), Anciennes et Nouvelles Aristocraties de 1880 à Nos Jours. Paris: Maison des sciences de l'homme 65-80.

Dronkers, Jaap. 2008. Declining Homogamy of Austrian-German Nobility in the $20^{\text {th }}$ Century? A Comparison with the Dutch Nobility. Historical Social Research/Historische Sozialforschung 33: 262-284.

2003. Has the Dutch Nobility Retained Its Social Relevance during the $20^{\text {th }}$ Century? European Sociological Review 19: 81-96.

Dronkers, Jaap, Schijf, Huibert. 2004. The Transmission of Elite Positions among the Dutch Nobility during the $20^{\text {th }}$ Century. In: E. Conze, M. Wienfort (eds.), Adel und Moderne: Deutschland im europaischen Vergleich im 19. und 20. Jahrhundert. Koln: Bohlau Verlag. 65-84.

Dworzaczek, Włodzimierz. 1959. Genealogia. Warszawa: PWN.

Główny Urząd Statystyczny. 2018. Rejestr TERYT (http://eteryt.stat.gov.pl/).

Jakubowska. Longina. 2005. Memory-Making among the Gentry in Poland. In: F. Cappelletto, Francesca (ed.), Memory and World War II: An Ethnographic Approach. Oxford: Berg Publishers. 155-176.

2009. White and Red Forever: Nobility and the Socialist State in Poland. Presented at the Nobility in Europe during the $20^{\text {th }}$ Century: Memories, 
Loyalties and Advantages in Context Conference. Florence, European University Institute.

2012. Patrons of History: Nobility, Capital and Political Transitions in Poland. Farnham: Ashgate Publishing.

Jakubowski, Adam, Bobrzyński, Michał, Pawiński, Adolf, Szymanowski, Michał. 1889. Volumina legum. Prawa, konstytucye y przywileje Królestwa polskiego, Wielkiego Ksiestwa litewskiego y wszystkich prowincyi należacych na walnych seymiech koronnych od seymu Wiźlickiego roku pańskiego 1347 aż do ostatniego seymu uchwalone. Volumen nonum ab anno 1782 ad annum 1792 acta Reipublicae continens. Krakow: Akademia Umiejętności.

Jedlicki, Jerzy. 2008. Błędne koło: 1832-1864. Warsaw: Instytut Historii PAN, Wydawnictwo Neriton.

Korom, Philipp, Dronkers, Jaap. 2015. Nobles among the Austrian Economic Elite in the Early Twenty-First Century. In: N. H. Bijleveld, J. Dronkers, Y. Kuiper (eds.), Nobilities in Europe in the Twentieth Century. Reconversion Strategies, Memory Culture and Elite Formation. Leuven: Peeters Pub \& Booksellers. 281-304.

Minakowski,MarekJerzy. 2007.DziesięćtomówPSBnajednejtablicygenealogicznej. "Ci wielcy Polacy to nasza rodzina”. In: R. T. Prinke (ed.), Megabajty dziejów: informatyka w badaniach, popularyzacji i dydaktyce historii. Poznan: Instytut Historii Uniwersytetu im. Adama Mickiewicza. 97-106.

2016. Modelowanie rozkładu kapitału ekonomiczno-społeczno-kulturowego poprzez genealogię masową. Przeszłość Demograficzna Polski 38: 63-88. (https://doi.org/10.18276/pdp.2016.4.38-03).

2018a. Genealogia Potomków Sejmu Wielkiego (http://www.sejm-wielki.pl/). 2018b. Wielka Genealogia Minakowskiego (http://wielcy.pl/).

Narojczyk, Krzysztof. 2003. Nowe perspektywy elektronicznych wydań materiałów źródłowych: uwagi na marginesie cyfrowej edycji "Herbarza polskiego” Adama Bonieckiego. Studia Źródłoznawcze: 109-114.

Norrby, Göran. 2015. The Transformation of the Swedish Aristocracy. In: N. H. Bijleveld, J. Dronkers, Y Kuiper (eds.), Nobilities in Europe in the Twentieth Century. Reconversion Strategies, Memory Culture and Elite Formation. Leuven: Peeters Pub \& Booksellers. 73-96.

Polski słownik biograficzny. 1935. Polska Akademia Umiejętności, Instytut Historii Polskiej Akademii Nauk.

Smoczyński, Rafał, Zarycki, Tomasz. 2012. Współczesne polskie elity postszlacheckie w kontekście europejskim. Kultura i Społeczeństwo: 261-292. 2017. Totem inteligencki. Arystokracja, szlachta i ziemiaństwo $w$ polskiej przestrzeni społecznej. Warsaw: Wydawnictwo Naukowe Scholar.

Stowarzyszenie Potomków Sejmu Wielkiego. n.d. Historia SPSW (http://spsw.pl/ en/historia-spsw). 
Świca, Małgorzata, Prinke, Rafał Tadeusz, Wisłocki, Jerzy, Bieniaszewski, Aadam, Biblioteka Kórnicka. 1997. Teki Dworzaczka (materiały historycznogenealogiczne do dziejów szlachty wielkopolskiej XV-XX w.). Poznań: Biblioteka Kórnicka PAN.

Sztárayné Kézdy, Éva. 2009. Egy eltûnt réteg nyomában: egykori arisztokrata családok leszármazottai a mai Magyarországon. Budapest: Gondolat.

Żychliński, Teodor. 1879. Złota ksiega szlachty polskiej. Poznań: Jarosław Leitgebe. 